\title{
Research on the application of information and Internet technology in English Education
}

\author{
Li Jing, Dai Wei
}

Nanchang Institute of Science \& Technology, Nanchang 330108, China

Key words: information technology; English education; teaching model;

\begin{abstract}
With the development of information technology, the information technology has been widely used in many fields, such as the development of the society. To a certain extent, which has also formed a dependence on information and Internet technology, of course, this also includes education. With the continuous strengthening exchanges between countries in the world, English has become a language of international exchange, and it is an important carrier of national and state exchanges, and it is the key to strengthen exchanges with china. It is of great significance to improve the teaching efficiency of English teaching by using the timeliness and interactivity of information and Internet technology to improve the efficiency of English teaching.
\end{abstract}

\section{Introduction}

With the rapid development and wide application of information and Internet technology, it has English education, is not simply the information technology and the Internet just as useful teaching demonstration tools, but is to realize the information and Internet technology and science to the real convergence. It not only can effectively mobilize the students' learning initiative, but also can optimize the teaching process, stimulate students' creative thinking, so as to cultivate their independent learning ability and independent innovation ability by using modern information technology to reform the traditional teaching model, combined with the scientific nature of the textbook and the interest of modern information technology,

\section{The development of information and Internet technology}

Information and Internet technology is one of the greatest scientific inventions created by man in twentieth Century, as a new carrier of information transmission, new information technology innovation, with the increasing popularity of the Internet technology and the extensive use is gradually changing people's way of life and production, caused a hitherto unknown information reform and industrial reform. Information and Internet technology mainly includes three stages of development, the first phase: experimental research stage (1969-1994). When the United States and the former Soviet Union competing for hegemony, in order to ensure the military communication to maintain a smooth nuclear weapons in combat, the United States Department of defense established ARPANET in 1969, the ARPANET was renamed "internet" in 1983. The second stage: the starting stage of social application (1994-2001), in 1994, the United States allows commercial capital to intervene in the construction and operation of the Internet, the Internet technology out of the laboratory to become open to the community of technology, began to penetrate into all walks of life. At this stage, the development of information and Internet technology is mainly reflected in the rich network resources, the increase in the number of users and the emergence of a large number of sites. The third stage: the stage of social development (2001 up to now), in 21st Century, the rapid development of broadband, wireless communications technology, has created favorable conditions 
for the application of information and Internet technology and the broadening of the scope of application. At the same time, the size of the network and the number of users continues to increase, the information and Internet technology has gradually applied to the financial, commercial, public services, news and publishing, education and other fields.

\section{The advantages of information and Internet technology in English Teaching}

Conducive to communication at any time. Information and Internet technology have created an educational form and platform for English language education. In the special period of the outbreak of "SARS" in 2003, many colleges and universities stopped teaching activities, so that college students can only stay at home or in the bedroom. In this special period, because of the limitation of the scope of activities, it is difficult for teachers and students to communicate with each other. Information and network technology can make the teaching resources not limited by time and space, and make the teaching activities smoothly. If we can make use of information and Internet technology reasonably and effectively, people can break the limitation of time and space, and achieve the purpose of communication anytime, anywhere.

Conducive to the sharing of quality resources. In some well-known universities, almost every day will invite well-known experts, professors and scholars to hold lectures and seminars. According to the traditional form, it is difficult to hear what they are saying if they are not on the spot. But with the information and Internet technology, only need to live on the site, then there will be more people to enjoy these high-quality resources. Many colleges and universities in the United States have done a good job in this regard, such as the Georgia Institute of Technology Talks @ Tech", they invited Bill and other experts in the field of information and Internet technology to host a network lectures. This not only saves Bill Gates to go to the scene of the trouble, and greatly increase the students as well as the well-known experts in the field of communication opportunities to interact with him, so as to effectively improve the utilization rate of resources and social learning.

Beneficial for students to participate in class activities. The process of instant sharing is a form of interaction, each participant is the protagonist of the interactive process. In the process of traditional English education in general is to organize the teaching in the class as a unit, most of all is to take teachers as the main body of the teaching, students' passive acceptance of knowledge, the traditional teaching mode is obviously not conducive to the cultivation of the students' independent thinking and independent learning ability. It can create an interactive mode by use of information technology and the Internet, so that students in a way that is a passive recipient, but also to participate in the main body, teachers appropriate guidance to students, so that students can understand the knowledge, which plays an important role in cultivating students' ability to master knowledge.

Help students to carry out self-education. Because the Internet is stored in a large amount of information, information and Internet can provide a large number of high-quality data in two aspects of depth and breadth, which can effectively make up for the traditional English education only provides insufficient knowledge and theory, which makes students to learn English can start from the problem. Through the search and analysis of problems on the Internet, students can learn new knowledge and theories. Through the information and Internet technology, students can understand and study the knowledge points brought by the problem more comprehensively and concretely, which strengthens the students' ability of self education in the process of solving problems. 


\section{The optimization of information and Internet technology in English Teaching}

Make full use of information and Internet technology to carry out real-time communication of knowledge. With the development of information and network technology, the use of information and Internet technology can realize the modernization and informatization of English education of colleges and universities, the use of large database in the Internet, English education can provide rich and diversified teaching materials, use of these high-quality teaching materials for English education better service. English learning website, listening, teaching materials can be obtained easily from the Internet, and teachers can also use the network video to enrich the teaching quality of English classroom teaching, in order to obtain good teaching effect. For example, students can download the hearing content of TED, VOA, BBC through the network, students' listening ability can be trained, which is the most effective way to train students to listen. In addition, WeChat, QQ, micro-blog, post bar, network forum, Renren network platform for teachers and students to create opportunities for communication, students can not be difficult to understand the contents of the classroom on the network platform with the teacher to communicate and interact in real time. Moreover, it is helpful to improve the level and quality of English teaching by summarizing and summarizing the knowledge points.

Innovative English education forms, mobilize the enthusiasm of students. The traditional mode of English education is to adopt the "indoctrination" style of teaching, and it is difficult to fully mobilize the initiative of students. We should make full use of modern information and Internet technology to reform and innovate the traditional English teaching mode, which is also an important embodiment of modern teaching concept. In the traditional teaching mode, teachers focus on the cultivation of students' English grammar and reading ability, while ignoring the teaching of spoken English. The modern teaching idea requires teachers should focus on teaching oral English teaching, using multimedia and group cooperation, create situational teaching form, stimulate students' interest in learning. We use situational teaching for example, teachers will be able to present a negotiation scenario for English students to use information technology and the Internet, let the students according to the situation in the form of negotiation, choose another negotiation topic, let the students perform in the form of group. Through this process, not only can cultivate students' ability to use spoken English, but also to cultivate students' social skills, to pave the way for students to enter the community.

Optimal evaluation mechanism. Curriculum evaluation plays a key role in the development and implementation of curriculum. Through the evaluation of the curriculum can be a comprehensive understanding of the learning situation of students, and then pave the way for the follow-up teaching work. The traditional English course is to test for the main assessment form, simply by test scores of students of curriculum evaluation, this evaluation model is too monotonous and procedures, can not reflect the concept of humane teaching. In the era of information and Internet technology, it is necessary to optimize the evaluation model of English teaching curriculum, and establish the evaluation form of information technology. The main method is to create electronic archives of students, the automatic generation of the evaluation model, record students' classroom learning situation in the life, realization and test scores in electronic files, and backup, to avoid the loss of electronic archives.

\section{Conclusion}

In short, with the rise of information and Internet technology, it has not only greatly reduced the 
difficulty of access to quality resources, but also provided a broad platform for teachers' teaching. Information and Internet technology have been integrated into English education, and became an important part of English education activities. Information and Internet technology can enrich the process of teaching, innovative educational model, real-time interactive communication, greatly inspired the enthusiasm of students to learn English, making English class to achieve the effect of half the effort. At the same time, information technology and Internet technology can optimize the teaching evaluation, comprehensive evaluation of students, and achieve a comprehensive improvement of the quality of students overall.

\section{Reference}

[1] Su Ke. The application of network news in the teaching of advanced English listening course [J]. Education Teaching Forum, Vol. 31, (2016) ,p.178-179.

[2] Wang Meng. Case study of inquiry teaching model in senior high school information technology curriculum [D]. Shenyang Normal University, (2016)

[3] Guo Meiguang. Strategies for cultivating students' oral English ability in secondary vocational school [J]. Science and Technology Innovation Herald, Vol.17, ,(2015) ,p.154-156.

[4] Meng Xing. The application of multimodal teaching model in English Vocabulary Teaching in junior high school [D]. Jilin University, (2015)

[5] Wen Haihua, Ding Tianhua, PETER Nash. Study on improving the ability of oral English Major Students [J]. Journal of Fujian Agriculture and Forestry University(Philosophy and Social Sciences), No.06, (2014) ,p.105-109.

[6] Wang Longyao, Wang Lan. Application of Internet in education and teaching [J]. China Educational Technology \& Equipment, No. 04, (2014) ,p.45-47.

[7] Liu Changjiang. Imbalance and reconstruction of College English Classroom Ecology in the context of information technology [D]. Shanghai International Studies University, (2013)

[8] Zhang Guanwen. Internet communication form evolution [D]. Shandong University, (2013)

[9] Ye Yisheng. In Higher Vocational English teaching and teachers' modern information technology literacy [J]. Journal of Kunming Metallurgy College, No.02, (2013) ,p.46-49.

[10] Fang Mengjie. With the support of information technology in College English classroom interaction model [D]. Nanchang University, (2012)

[11] Zhao Jinghong. The application and role of network technology in the development of College English teachers [D]. Jilin University, (2012)

[12] Wang Boran. Influence of English project learning model on learning motivation factors [D]. Shanghai International Studies University, (2012)

[13] Yang Yuanbo. Strategy and case study of English Vocabulary Teaching in information technology support middle school [D]. Huazhong Normal University, (2001)

[14] Wang Rong, Tian Jinping. On the cultivation of College Students' English autonomous learning ability [J]. Journal of Shanxi Normal University(Social Science Edition), 2011, (): 158-160. 
[15] Meng Yuanyuan. Multimedia technology in middle school English Teaching in the application of [J]. Science and Technology Innovation Herald, No. 02, (2011) ,p.158

[16] Xu Xiaojing. How to use the information technology to optimize English Teaching in senior high school [D]. Huazhong Normal University, (2008)

[17] Li Jing. The application of educational informationization in Higher Vocational English teaching [D]. Northwest Normal University, (2007)

[18] Ou Jie. Analysis and Countermeasures of English teaching based on Internet [D]. Guangxi Normal University, (2004) 